The Open Urology \& Nephrology
bentham open
JrossMark
Content list available at: www.benthamopen.com/TOUNJ/
DOI: $10.2174 / 1874303 \mathrm{X} 01710010020$

CASE REPORT

\title{
Community Acquired Acute Kidney Injury from Edible Agents: Report from a Developing Country, Bangladesh
}

Tabassum Samad*, Wasim M. Mohosin ul Haque, Muhammad A. Rahim, Sarwar Iqbal and Palash Mitra

Department of Nephrology, BIRDEM General Hospital, Shahbag, Dhaka 1000, Bangladesh

Received: May 04, 2016

Revised: September 09, 2016

Accepted: October 10, 2016

Abstract: Toxin is a common cause of community acquired acute kidney injury (AKI) which includes environmental toxins like plant toxins as well as various drugs and chemicals which are usually ingested for medicinal as well as recreational purposes.

Averrhoa carambola (Star fruit/ Kamranga) and Avorrhoa bilimbi are two such commonly used traditional remedies. They belong to family Oxalidaecae and contain high-levels of oxalic acid. AKI may occur after consuming concentrated juice due to deposition of oxalate crystals in the renal tubules.

Here we present two patients who developed AKI after ingestion of freshly made juice from A. bilimbi and star fruit. Both patients were diabetic and the juice was ingested on empty stomach with the belief of improving glycemic status. Initial presentation was GI upset in both scenarios. Patient with A. bilimbi toxicity had diabetic nephropathy and required hemodialysis. Renal biopsy revealed deposition of polarizable oxalate crystals in the patient who consumed A. bilimbi and acute tubular necrosis in the patient with star fruit toxicity. All cases regained normal renal function within three months.

We also present a patient who ingested raw fish gallbladder as a remedy for asthma. The patient presented with AKI within five days of ingestion and required hemodialysis. His highest serum creatinine was $10.4 \mathrm{mg} / \mathrm{dl}$ and fell to $1.7 \mathrm{mg} / \mathrm{dl}$ after four weeks. Cyprinol and related compounds in fish gallbladder are thought to be the cause of acute tubular necrosis in such cases.

The fourth patient developed AKI with rhabdomyolysis after consuming a locally made energy drink. He also required dialysis and serum creatinine gradually improved from $7.2 \mathrm{mg} / \mathrm{dl}$ to $1.4 \mathrm{mg} / \mathrm{dl}$ at discharge. The possibility of toxicity of caffeine, adulteration with other chemicals or ascorbic acid toxicity causing oxalate nephropathy could not be excluded.

All four patients developed AKI caused after ingesting easily available products and are presented here for public awareness. We believe proper knowledge and education can reduce toxin induced AKI in our society.

Keywords: Acute kidney injury, Community acquired AKI, Star fruit, Averrhoa bilimbi, Energy drink, Fish gallbladder poisoning, Bangladesh.

\section{INTRODUCTION}

Acute kidney injury(AKI) in developing countries is markedly different from AKI in developed countries [1]. The etiology and presentation of AKI in these countries reflect ecological characteristics, educational paucity, cultural practices and other socio-economic factors. One of the commonest causes of AKI in developing world is ingestion of toxic herbs or chemicals with belief of health benefit [2]. Here, we present four cases of AKI for public as well as physician awareness, which occurred after taking Averrhoa bilimbi, star fruit, fish gallbladder and an energy drink.

\subsection{Case 1}

A 38-year-old diabetic female presented with a one-day history of vomiting, back pain, oliguria and swelling of both

* Address correspondence to this author at the Department of Nephrology, BIRDEM General Hospital, 122,Kazi Nazul Islam venue, Shahbag, Dhaka 1000, Bangladesh; Tel: +8801711282434; E-mails: titlysamad@gmail.com, samadtabassum@yahoo.com 
lower limbs. She had taken around $250 \mathrm{ml}$ of Averrhoa bilimbi juice Fig. (1a) on an empty stomach for two days before developing the symptoms. She took the juice believing that it would reduce her blood glucose level. At the time of admission, the patient was conscious, oriented and hemodynamically stable. She had mild bilateral pedal edema but her lungs were clear. Fundoscopic examination revealed mild non-proliferative retinopathy. Bed side urine had 1(+) proteinuria. Investigations showed serum creatinine $4.7 \mathrm{mg} / \mathrm{dl}$ with a rising trend. Her urinalysis report and ultrasonogram of kidneys were unremarkable. Other investigations are listed in Table 1. She required four sessions of hemodialysis. Percutaneous biopsy from left kidney was performed which showed mild mesangial proliferation with oxalate crystals in tubules (Figs. 1b and c).which were polarizable (Fig. d). The patient was discharged on day 10 as serum creatinine was steadily decreasing without dialysis. Her renal function gradually returned to normal on subsequent follow up visits (serum creatinine $1.3 \mathrm{mg} / \mathrm{dl}$ at four weeks and $0.95 \mathrm{mg} / \mathrm{dl}$ at 12 weeks).

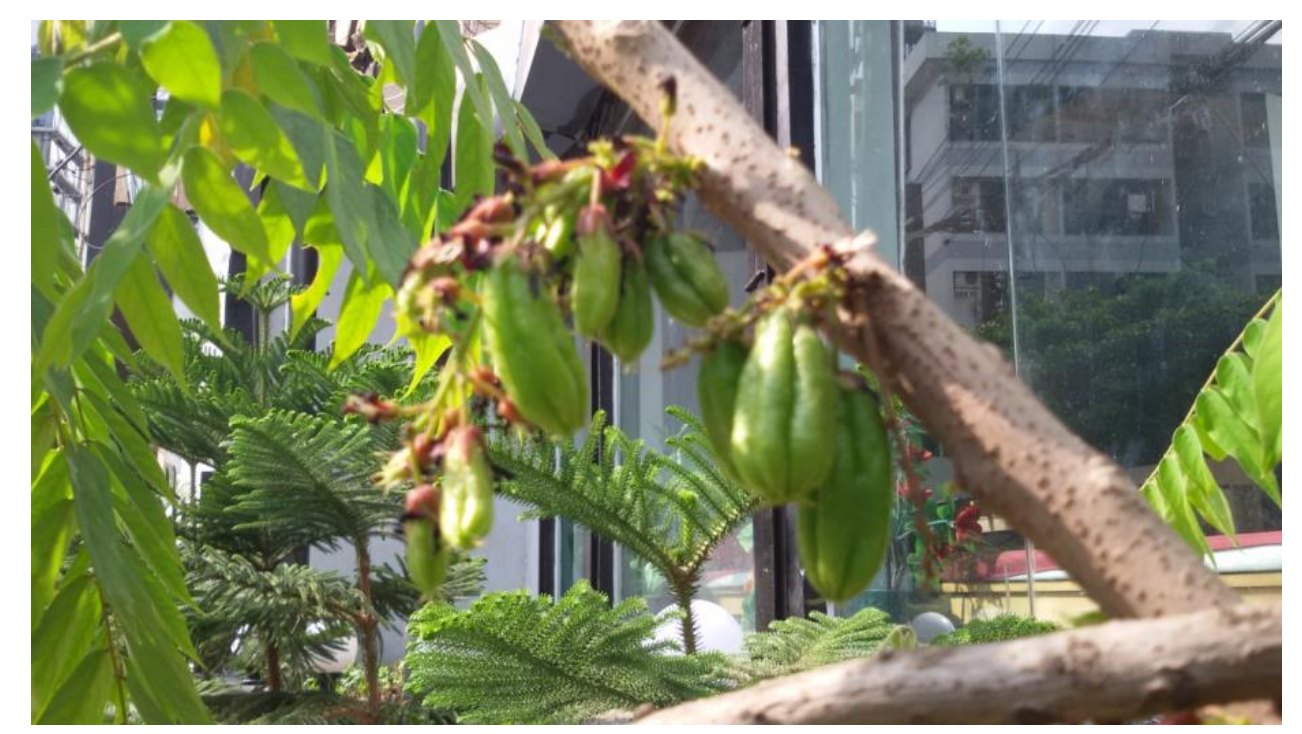

Fig. (1a). Ilustration of Avorrhoa bilimbi tree and fruit. It isa small tree 5-10 meters high, usually seen in the tropics. Bilimbi is fruits are cylindrical and produced in clusters.[7]Photo Courtesy: Dr.Muhammad Abdur Rahim FCPS (Medicine).

Table 1. Abnormal laboratory findings of the patient with A. bilimbi toxicity.

\begin{tabular}{|c|c|c|}
\hline Laboratory Test & Patient's Value & Reference Range \\
\hline $\mathrm{Hb}(\mathrm{gm} / \mathrm{dl})$ & 11.8 & $11.5-16$ \\
\hline Total leucocyte count/cmm of blood & 8000 & $4000-11,000$ \\
\hline Neutrophil (\%) & 83 & $40-70$ \\
\hline Platelets /cmm of blood & $1,78,000$ & $1,50,000-4,50,000$ \\
\hline $\mathrm{ESR}\left(\mathrm{mm}\right.$ in $\left.1^{\mathrm{st}} \mathrm{hr}\right)$ & 50 & $<20$ \\
\hline Urea $(\mathrm{mg} / \mathrm{dl})$ & 245 & $20-40$ \\
\hline Serum creatinine $(\mathrm{mg} / \mathrm{dl})$ & 7.4 & $.67-1.2$ \\
\hline Random Blood Sugar(mmol/L) & 14 & $<11.1$ \\
\hline $\mathrm{HbA} 1 \mathrm{C}(\%)$ & 8.5 & $<7$ \\
\hline $\begin{array}{c}\text { Urine } \\
\text { Glucose } \\
\text { Protein } \\
\text { Pus Cell / HPF } \\
\text { RBC / HPF } \\
\text { Oxalate crystal } \\
\text { HbsAg, AntiHCV } \\
\mathrm{C}_{3,} \mathrm{C}_{4} \\
\text { ANA }\end{array}$ & $\begin{array}{c}+ \\
+ \\
5-8 \\
\text { Nil } \\
\text { Not found } \\
\text { Negative } \\
\text { Normal range } \\
\text { Negative }\end{array}$ & \\
\hline
\end{tabular}




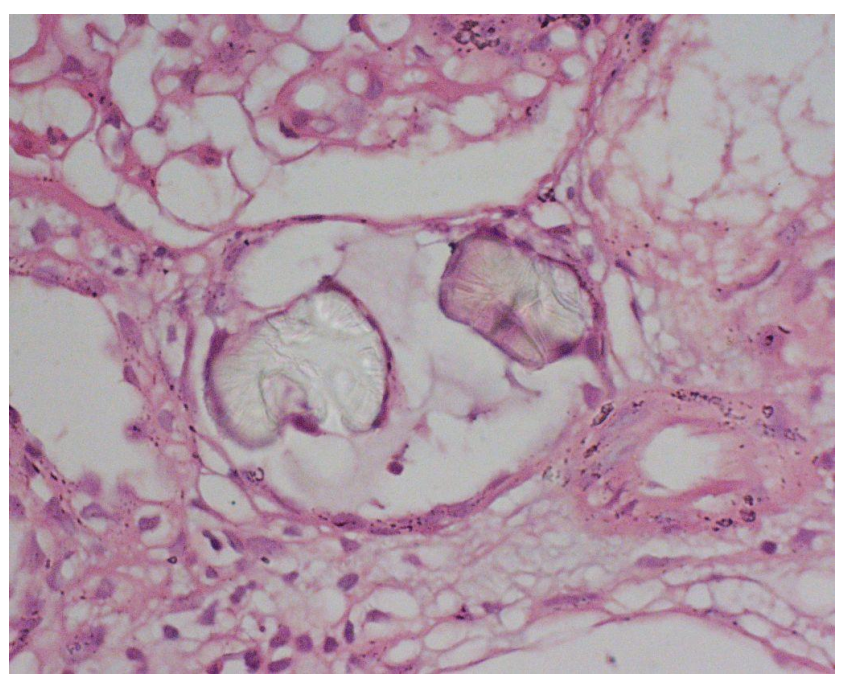

Fig. (1b). Light microscopic examination (Hematoxilin and eosinophil stain) of renal tissue showing crystals within the tubules.

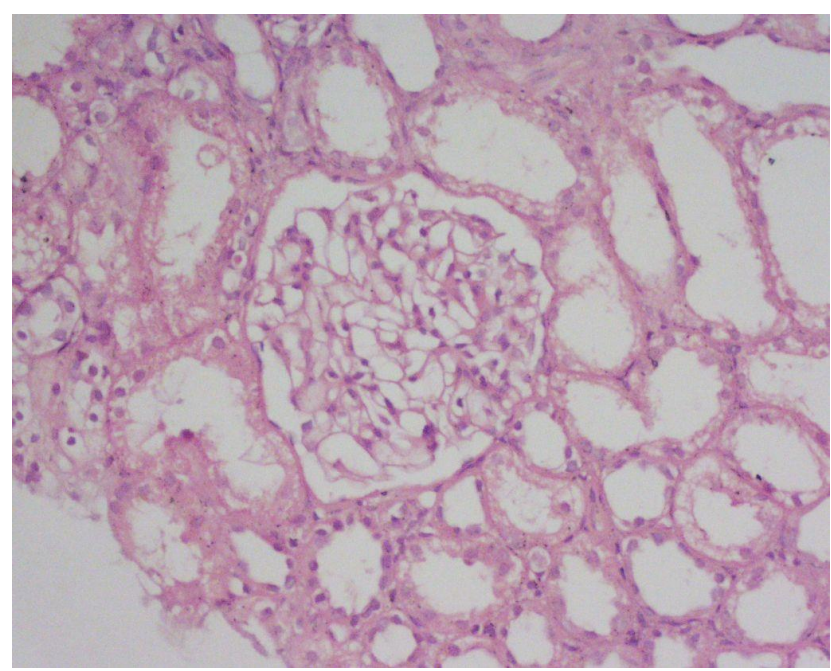

Fig. (1c). Light microscopic examination (Hematoxilin and eosinophil stain) of renal tissue showing mild mesangial proliferation.

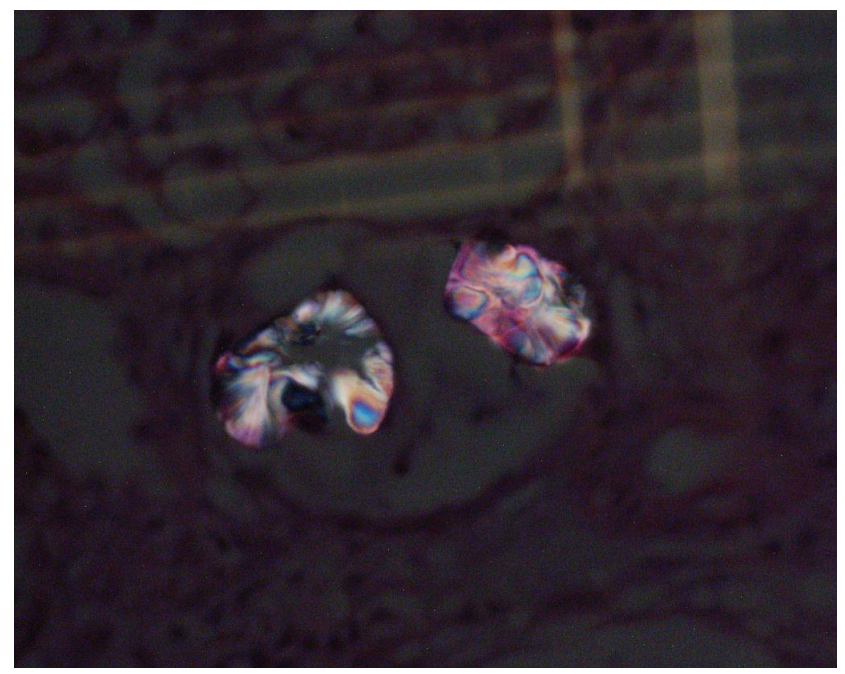

Fig. (1d). Examination of renal tissue showing oxalate crystals within tubules under polarized microscopy. 


\subsection{Case 2}

A 42-year-old diabetic male was referred with the diagnosis of AKI (Serum creatinine $3.2 \mathrm{mg} / \mathrm{dl}$ ). The history revealed that the patient had experienced several episodes of vomiting and diffuse abdominal pain within two hours of consuming juice prepared from a half kilogram of star fruit three days prior. On the following day, he noticed reduced urine output. During this period, he was ambulant and developed no features of hypotension. There was no other history suggestive of AKI. He consumed the juice to improve his glycemic status. On examination, the patient was looking ill but oriented. He was euvolemic. His blood pressure was 130/80 mm Hg, temperature was normal. No abnormalities on systemic examination were found. Bed side urine was negative for albumin. Routine urinalysis was also normal, no oxalate crystals were found. His hemogram and ultrasonogram of kidneys were unremarkable. All markers of vasculitis were negative. Renal biopsy findings consisted of acute tubular necrosis (Fig. 2a).After admission, his serum creatinine level continued to a peak of $8.5 \mathrm{mg} / \mathrm{dl}$ and returned to normal within eight days with conservative management. (Fig. 2b). He was discharged with a serum creatinine of $1.2 \mathrm{mg} / \mathrm{dl}$.

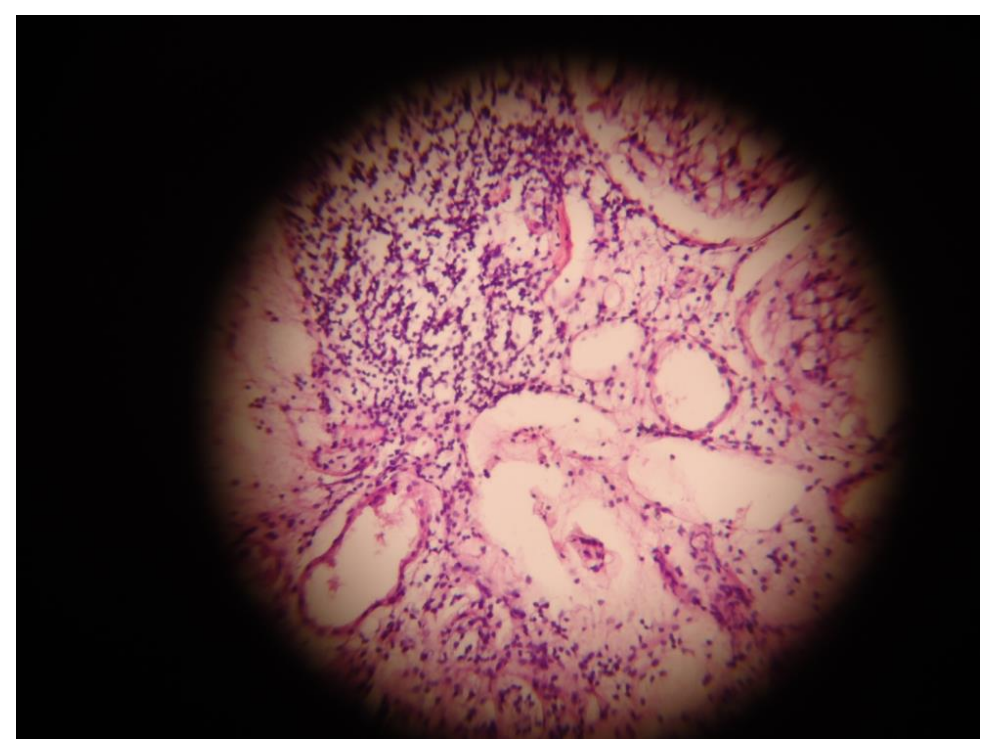

Fig. (2a). Light microscopic examination of renal tissue showing global hyalinization of glomeruli, dilatation of tubules, deposition of crystalline and debris and marked interstitialedema suggestive of Acute tubular necrosis.

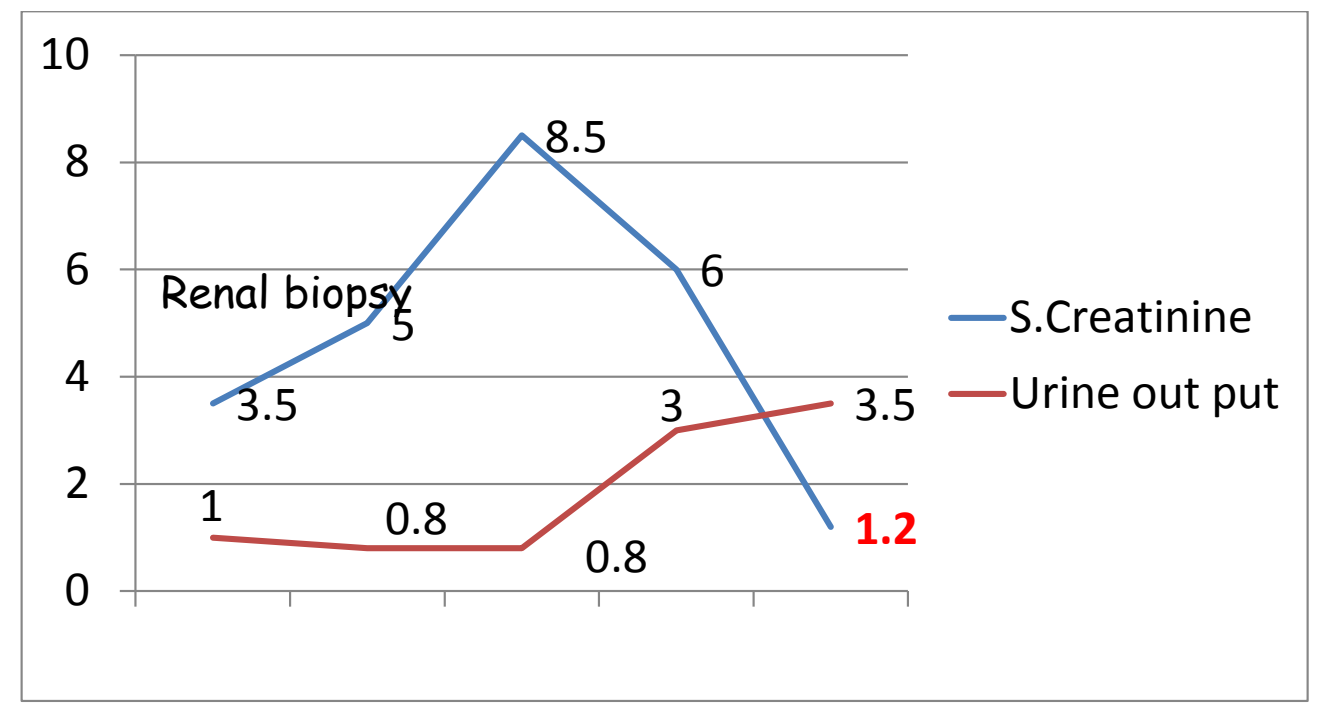

Fig. (2b). Reciprocal relation of serum creatinine level and urine output in star fruit induced acute kidney injury patient. 


\subsection{Case 3}

A 51-year-old male with diabetes and hypertension was referred with AKI (serum creatinine 3.0mg/dl). He had a history of vomiting, abdominal pain and anorexia which developed within two hours of ingestion of three raw fish gallbladders which he had taken five days prior with a belief of improvement of asthma. He noticed gradual reduction in urine volume. During this time, the patient neither developed any features suggestive of hypotension nor was dehydrated. There was no history of consumption of any other nephrotoxic food or drug. He had been taking Ramipril $2.5 \mathrm{mg}$ once daily for one year. On examination, he was ill-looking, mildly edematous and icteric. His pulse was $82 / \mathrm{min}$, blood pressure was 150/80 $\mathrm{mmHg}$. He was afebrile and his Glasgow Coma Scale (GCS) was 15/15. Other systemic examinations revealed no abnormality. His serum creatinine was $3.0 \mathrm{mg} / \mathrm{dl}$ at the time of referral but it continued to rise after admission and hemodialysis was commenced. He declined renal biopsy. Other investigations are listed in Table 2. Hemodialysis was discontinued after seven sessions and the patient was discharged as his serum creatinine was improving. His altered liver function was improved way before improvement of renal function. He was discharged after two weeks of hospitalization with a serum creatinine of $2.2 \mathrm{mg} / \mathrm{dl}$ and up to after two weeks, his serum creatinine came down to1.7 mg/dl (Fig. 3).

Table 2. Important investigation of patient with acute fish gallbladder poisoning.

\begin{tabular}{|c|c|c|}
\hline Laboratory Test & Patient's Value & Reference Value \\
\hline $\mathrm{Hb}(\mathrm{gm} / \mathrm{dl})$ & 12.6 & $11.5-16$ \\
\hline Total leucocyte count $\left(/ \mathrm{mm}^{3}\right)$ & 8,500 & $4000-11000$ \\
\hline N-L-M-E (\%) & $77-13-08-02$ & \\
\hline Platelet count $\left(/ \mathrm{mm}^{3}\right)$ & $2,50,000$ & $150000-450000$ \\
\hline \multicolumn{3}{|c|}{$\begin{array}{c}\text { Urine R/M/E } \\
\text { Albumin Negative } \\
\text { Pus cell/HPF 8-10 } \\
\text { RBC/HPF 2-3 }\end{array}$} \\
\hline SGOT (IU/L) & 169 & Upto 37 \\
\hline SGPT (IU/L) & 1580 & Upto 40 \\
\hline S.Bilirubin (mg/dl) & 9 & $.4-1.2$ \\
\hline Alkaline phosphatise (U/L) & 167 & $39-130$ \\
\hline Total protein $(\mathrm{gm} / \mathrm{dl})$ & 70.4 & $63-82$ \\
\hline S.Albumin(gm/dl) & 37 & $35-57$ \\
\hline HbsAg & Negative & \\
\hline AntiHCV & Negative & \\
\hline Anti HEV & Negative & \\
\hline
\end{tabular}

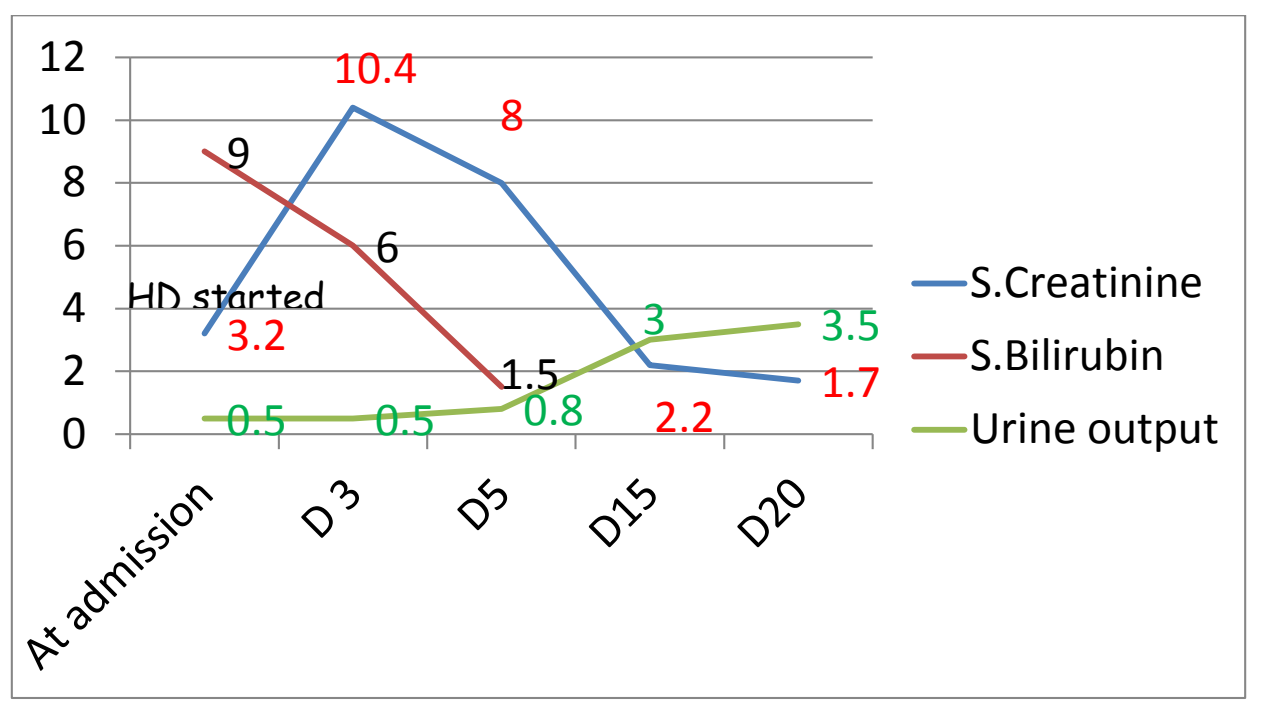

Fig. (3). Management and outcome of patient with acute fish gallbladder poisoning. 


\subsection{Case 4}

A 32-year-old man who was normotensive and not diabetic was referred from a local hospital with the diagnosis of AKI. His illness started three days prior to admission when he took a locally available energy drink(Moon Power) and felt very hot and restless. He developed severe anorexia, nausea and vomiting three hours later followed by decrease in urine volume for one day. He also developed mild puffiness of the face and feet. He was referred to us on the $3^{\text {rd }}$ day when his serum creatinine was $6.8 \mathrm{mg} / \mathrm{dl}$.He denied taking any medication or herbal products recently. On examination, he was looking ill and had mild ankle edema. His pulse was 96/min and BP 160/80 mm Hg. Systemic examination was unremarkable. His bed side urinary albumin was positive $(1+)$ but there were no red blood cells or casts on routine microscopic examination of urine. Renal function test revealed urea $168 \mathrm{mg} / \mathrm{dl}$, serum creatinine $7.2 \mathrm{mg} / \mathrm{dl}_{\mathrm{and}} \mathrm{TCO}$ $18 \mathrm{mmol} / \mathrm{L}$ on serum electrolyte test. Urinary total protein revealed $0.75 \mathrm{gm} /$ day and ultra sonogram of kidneys and urinary bladder showed bilateral swollen kidneys (Fig. 4). His serum creatine phosphokinase was 7280 U/L (24-195U/L). All other markers of infection were negative. He was treated with two sessions of dialysis, thereafter his serum creatinine steadily declined without dialysis and finally he was discharged on $10^{\text {th }}$ day with serum creatinine of $1.4 \mathrm{mg} / \mathrm{dl}$.

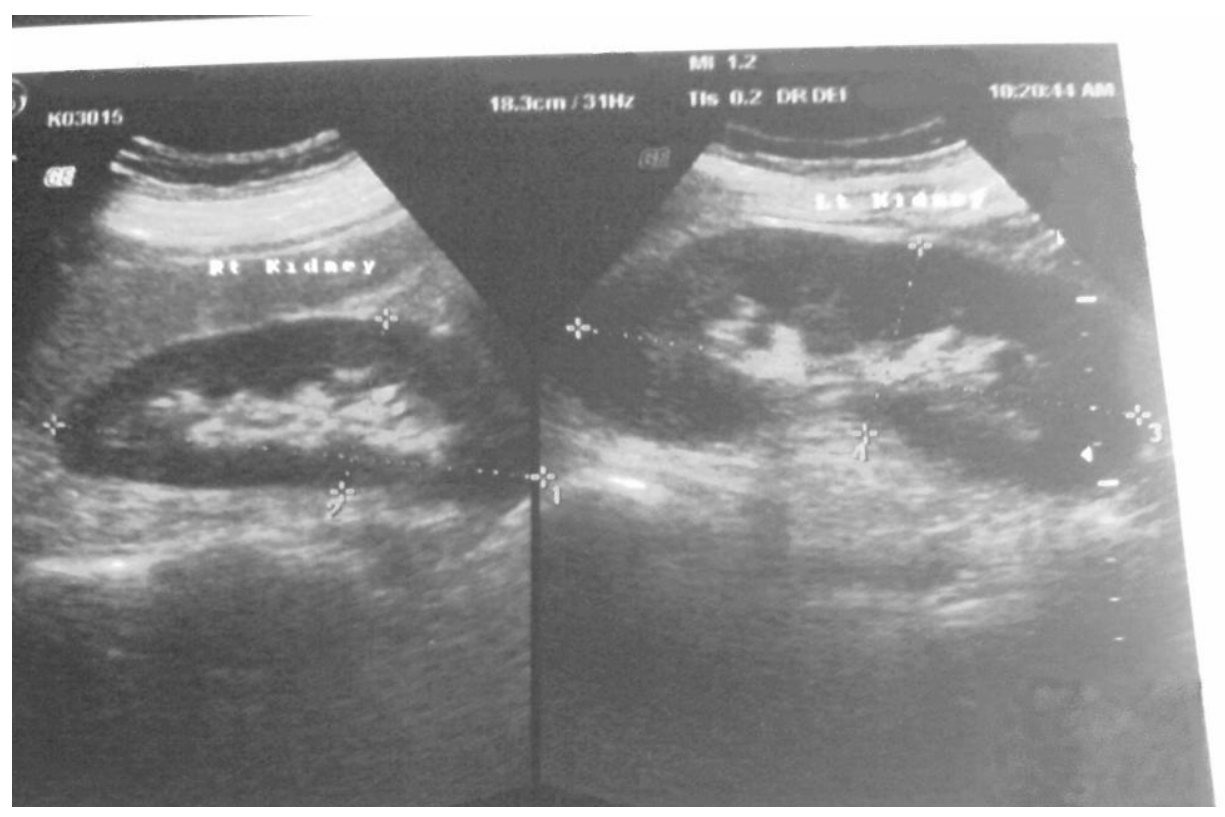

Fig. (4). USG of whole abdomen of patient with energy drink poisoning showing bilaterally swollen kidneys with reduced cortical echogenicity. PC system is not dilated.

\section{DISCUSSION}

Averrhoa bilimbi and Averrhoa carambola (Star fruit), both belong to the family of Oxalidaceae, the members of which contain high oxalic acid. The oxalic acid content of A. bilimbi is highest in half- ripe fruit (8.57-10.32 mg/gm) and that of $A$. carambola is $80-730 \mathrm{mg} / \mathrm{dl}$ [3 - 5].Oxalate excretion mainly occurs through the kidneys and therefore an increased oxalate load may predispose to tubular precipitation and renal failure [6, 7] the two cases reported here, the first patient took total $500 \mathrm{ml}$ of bilimbi juice in two days and the second patient ingested juice of 500 gram star fruit in one day. Although the exact amount of fruit or juice which may cause renal insufficiency is yet not known [5], it is necessary to determine the minimum amount causing acute oxalate nephropathy. It is also important to identify any additional criteria which might contribute to the AKI. A. bilimbi had been used in different communities to treat dyslipidemia, high blood pressure and diabetes mellitus and A. carambola had been used for headache, upper respiratory tract infections, vomiting, restlessness, haemorroids and diabetes[7]. There are also few reports on medicinal properties of $A$. bilimbi [8,9]. Both the patients took the juice with the belief of improving their diabetes status. Gastrointestinal symptoms have been the most common presenting complaints in all reported cases of oxalatetoxicity $[3,5,10,11]$ aswas the casein our patients. Our first patient also had acute back pain which had also been described by Neto MM, et al. [5]. We could not find oxalate crystals in the urine in either cases which could be due to rapid clearance of oxalate crystals [3] or might reflect our inexperience in dealing with such a relatively new entity. 
Although there are several case reports of acute oxalate nephropathy due to multipleagents [12 - 15], reports on AKI due to A. bilimbiare very few $[3,7,10]$. We performed a renal biopsy in both patients and found oxalate crystals in first patient only and features of acute tubular necrosis with tubular dilatation in second. Although the presence of calcium oxalate on kidney biopsy is required for the diagnosis of oxalate nephropathy it is not a specific finding and the presence of tubular dilatation, as in the second patient, is a consistent finding in both acute and chronic oxalate nephropathy [16]. Hyperoxaluric AKI also may have the characteristic features of acute tubular necrosis [17]. Our second patient had previously normal renal function which is very rarely reported as star-fruit toxicity tends to occur in those with baseline renal dysfunction [5]. The patient with bilimbi toxicity had diabetic nephropathy whereas all cases of $A$. bilimbi toxicity reported by Bakul et al. [7] had previously normal renal function. As in most reported cases the serum creatinine in both our patients did improve, but AKI remains a risk factor for CKD over the long term and is therefore important $[3,5,7]$.

AKI following consumption of raw gallbladder of grass carp has sporadically been reported in Taiwan, Korea, Hong Kong, India, Japan and United States [18]. The most common fish species from which gall bladders are eaten is the grass carp, family Cyprinidae [19]. Raw fish gallbladder is used as an alternative remedy for some chronic disorders like asthma, rheumatism, eczema, visual disturbance and impotance in rural part of south-east Asia [20]. In certain quantities it may produce systemic toxicities like acute hepatitis and acute renal failure [18]. The toxin is believed to be cyprinol sulphate or cyprinol, a bile acid [19]. Our third patient ingested three medium sized raw fish gall bladders and upon presented to hospital he already had renal and liver involvement. Hepatic derangement usually occurs earlier but may happen concomitantly with renal insufficiency and spontaneous resolution of altered liver function may occur within a few days as in our patient [18]. Consumption of gallbladder from smaller fish is common in some parts but there is no report of causing severe acute renal disease from this which may either suggest lack of case reporting or less toxicity, both of which remain unknown. Toxic effects from gallbladder ingestion from carp do not always occur [19]. However whenever a patient with AKI and hepatitis denies exposure to any drug or toxin, the possibility of ingestion of raw gallbladder should be raised [18]. In short term follow up of our patient renal function did not reach normal level therefore patients with AKI induced by gall bladder toxicity should be followed up long term to see whether they contribute to total chronic kidney disease pool.

Our final patient developed symptoms after taking energy drink. Energy drinks are reported to cause insomnia, shakiness, palpitation, headache, gastrointestinal upset, chest pain and seizure [21]. Regarding renal failure, only $3(0.18 \%)$ out of 166 cases of adverse events for energy drinks were reported to Food and Drug Administration (FDA) between 2004 and 2012 [22]. The ingredients of most of the energy drinks include caffeine, taurine, ginseng root, guarana, glucose, inositol, citric acid,ascorbic acid, glucoronolactone etc. The amount of guarana, taurine and ginseng found in most energy drinks occur at low levels; therefore, they are neither therapeutic nor lead to adverse effects [23]. There are also no known reports of kidney injury related to glucose or glucoronolactone [24]. Caffeine and ascorbic acid are the two potential ingredients with any link to renal injury. Though cases of caffeine overdose are relatively rare, AKI along with rhabdomyolysis was reported by Campana et al., with doses of $10 \mathrm{gm}$ and higher. Lesser amounts can be detrimental if taken with alcohol [25]. Ascorbic acid in high doses can cause oxalate nephropathy [13]. In our patient, we could not verify the exact amount of caffeine in the drink. Product contamination or adulteration could also not be entirely dismissed. We also could not identify the presence and/or amount of ascorbic acid in the consumed drink therefore the possibility of oxalate nephropathy could also not be excluded. According to the "Nerango adverse drug reaction probability scale", a causality assessment tool, our case fits into a probable drug reaction case [26].

\section{CONCLUSION}

Community acquired AKI is a major problem in developing tropical countries. This AKI is however, preventable. Prevention requires adopting a public health approach, including campaigns to raise awareness about safe use of herbs, pesticides and chemicals and other alternative remedies. Timely referral of patients with AKI to centers with dialysis facilities and their subsequent follow up will improve overall outcome.

\section{CONFLICT OF INTEREST}

The author confirms that this article content has no conflict of interest.

\section{ACKNOWLEDGMENTS}

Declared none. 


\section{REFERENCES}

[1] Cerda J, Bagga A, Kher V, Chakravarthi RM. The contrasting characteristics of acute kidney injury in developed and developing countries. Nat Rev Nephrol 2008; 4: 138-53.

[2] Luyckx VA, Naicker S. Acute kidney injury associated with the use of traditional medicines. Nat Clin Pract Nephrol 2008; 4(12): 664-71. [http://dx.doi.org/10.1038/ncpneph0970] [PMID: 18838981]

[3] Nair S, George J, Kumar S, Gracious N. Acute oxalate nephropathy following ingestion of Averrhoa bilimbi juice. Case reports in nephrology [Internate] 2014. June 4 [cited 2016 February 15]; Volume. Article ID Available from: [http://dx.doi.org/10.1155/2014/240936]

[4] Moysés Neto M. Star fruit as a cause of acute kidney injury: a case report. J Bras Nefrol 2014; 36(2): 118-20. [Editorial] [http://dx.doi.org/10.5935/0101-2800.20140019] [PMID: 25055349]

[5] Neto MM, Silva GE, Costa RS, Neto OMV, Cairasco NG, Lopes NP, et al. Star fruit: simultaneous neurotoxic and nephrotoxic effects in people with previously normal renal function 2009; 2: 485-88. NDT Plus [Internet]. 2009 August 18 [cited 2016 February 15] [http://dx.doi.org/10.1093/ndtplus/sfp108]

[6] Niticharoenpong K, Chalermsanyakorn P, Panvichian R, Kitiyakara C. Acute deterioration of renal function induced by star fruit ingestion in a patient with chronic kidney disease. J Nephrol 2006; 19(5): 682-6. [PMID: 17136702]

[7] Bakul G, Unni VN, Seethaleksmy NV, et al. Acute oxalate nephropathy due to Averrhoa bilimbi fruit juice ingestion. Indian J Nephrol 2013; 23(4): 297-300. [http://dx.doi.org/10.4103/0971-4065.114481] [PMID: 23960349]

[8] Ambili S, Subramoniam A, Nagarajan NS. Studies on the antihyperlipidemic properties of Averrhoa bilimbi fruit in rats. Planta Med 2009; 75(1): $55-8$

[http://dx.doi.org/10.1055/s-0028-1088361] [PMID: 19031370]

[9] Pushparaj P, Tan CH. Effects of Averhoabilimbi leaf extracts on blood glucose and lipids in streptozocin -diabetic rats. Journal of ethonopharmacology 2000; 72: 69-76.

[10] Billah MM, Rahman MA, Rahim MA, Swarna AT, Mitra P, Chowdhury TA, et al. Acute kidney injury following ingestion of Averhoa bilimbi juice. Bangladesh Crit Care J 2015; 3(2): 71-3.

[http://dx.doi.org/10.3329/bccj.v3i2.25115]

[11] Neto MM, da Costa JA, Garcia-Cairasco N, Netto JC, Nakagawa B, Dantas M. Intoxication by star fruit (Averrhoa carambola) in 32 uraemic patients: treatment and outcome. Nephrol Dial Transplant 2003; 18(1): 120-5. [http://dx.doi.org/10.1093/ndt/18.1.120] [PMID: 12480969]

[12] Sasaki M, Murakami M, Matsuo K, et al. Oxalate nephropathy with a granulomatous lesion due to excessive intake of peanuts. Clin Exp Nephrol 2008; 12(4): 305-8.

[http://dx.doi.org/10.1007/s10157-008-0046-5] [PMID: 18335167]

[13] Lawtom IM, Conway LT, Crosson JT, Smith CL, Abraham PA. Acute oxalate nephropathy after massive ascorbic acid administration 1985.

[14] Seo JW, Lee JH, Son IS, et al. Acute oxalate nephropathy caused by ethylene glycol poisoning. Kidney Res Clin Pract 2012; 31 (4): 249-52. [http://dx.doi.org/10.1016/j.krcp.2012.09.007] [PMID: 26889430]

[15] Getting JE, Gregoire JR, Phul A, Kasten MJ. Oxalate nephropathy due to juicing: case report and review. Am J Med 2013; 126(9): 768-72. [http://dx.doi.org/10.1016/j.amjmed.2013.03.019] [PMID: 23830537]

[16] Glew RH, Sun Y, Horowitz BL, et al. Nephropathy in dietary hyperoxaluria: A potentially preventable acute or chronic kidney disease. World J Nephrol 2014; 3(4): 122-42. [http://dx.doi.org/10.5527/wjn.v3.i4.122] [PMID: 25374807]

[17] Albersmeyer M, Hilge R, Schröttle A, Weiss M, Sitter T, Vielhauer V. Acute kidney injury after ingestion of rhubarb: secondary oxalate nephropathy in a patient with type 1 diabetes. BMC Nephrol 2012; 13: 141 [http://dx.doi.org/10.1186/1471-2369-13-141] [PMID: 23110375]

[18] Lin YF, Lin SH. Simultaneous acute renal and hepatic failure after ingesting raw carp gall bladder. Nephrol Dial Transplant 1999; 14(8): 2011-2.

[http://dx.doi.org/10.1093/ndt/14.8.2011] [PMID: 10462287]

[19] Xuan BH, Thi TX, Nguyen ST, Goldfarb DS, Stokes MB, Rabenou RA. Ichthyotoxic ARF after fish gallbladder ingestion: a large case series from Vietnam. Am J Kidney Dis 2003; 41(1): 220-4. [http://dx.doi.org/10.1053/ajkd.2003.50008] [PMID: 12500240]

[20] Patnaik R, Kar SS, Ray R, Mahapatro S. Indian carp (Labeo rohita) gall bladder poisoning-report of four cases in a single family. Indian J Pediatr 2011; 78(6): 749-52. [http://dx.doi.org/10.1007/s12098-010-0329-1] [PMID: 21207198]

[21] Nordt SP, Vilke GM, Clark RF, et al. Energy drink use and adverse effects among emergency department patients. J Community Health 2012; 37(5): 976-81

[http://dx.doi.org/10.1007/s10900-012-9549-9] [PMID: 22367607] 
[22] US Department of health and human services, FDA center for food safety and applied nutrition adverse event reporting system voluntary and mandatory reports on 5-Hour energy, monster energy, and rockstar energy drink Available at: http:/www.fda.gov/downloads/ AboutFDA/CentersOffices/ OfficeofFoods/CFSAN/ CFSANFOIA Electronic Reading Room/UCM328270.pdf.

[23] Greene E, Oman K, Lefler M. Energy drink-induced acute kidney injury. Ann Pharmacother 2014; 48(10): 1366-70. [http://dx.doi.org/10.1177/1060028014541997] [PMID: 24986632]

[24] Rath M. Energy drinks: what is all the hype? The dangers of energy drink consumption. J Am Acad Nurse Pract 2012; 24(2): 70-6. [http://dx.doi.org/10.1111/j.1745-7599.2011.00689.x] [PMID: 22324861]

[25] Campana C, Griffin PL, Simon EL. Caffeine overdose resulting in severe rhabdomyolysis and acute renal failure. Am J Emerg Med 2014; 32(1): 111.e3-4. [http://dx.doi.org/10.1016/j.ajem.2013.08.042] [PMID: 24079989]

[26] Naranjo CA, Busto U, Sellers EM, et al. A method for estimating the probability of adverse drug reactions. Clin Pharmacol Ther 1981; 30(2): $239-45$.

[http://dx.doi.org/10.1038/clpt.1981.154] [PMID: 7249508]

\section{(C) 2017 Samad et al.}

This is an open access article distributed under the terms of the Creative Commons Attribution 4.0 International Public License (CC-BY 4.0), a copy of which is available at: https://creativecommons.org/licenses/by/4.0/legalcode. This license permits unrestricted use, distribution, and reproduction in any medium, provided the original author and source are credited. 